Research

\title{
Hearing status of children under five years old in Jatinangor district
}

\author{
Wijana, Frino Abrianto, Shinta Fitri Boesoirie, Arif Dermawan \\ Department of Otorhinolaryngology Head and Neck Surgery. \\ Faculty of Medicine Universitas Padjadjaran/Dr. Hasan Sadikin Hospital, \\ Bandung
}

\begin{abstract}
Background: Hearing is one of the most influential factors in children developmental process. The critical period of hearing and speech development begins in the first 6 months of life and continues until the age of 3 years. World Health Organization estimates that one to three in a thousand births have sensorineural hearing loss (SNHL). Early detection of hearing loss is substantial so that the diagnosis can be established and appropriate intervention can be done earlier. Purpose: To determine the hearing status in children under five years of age in Jatinangor. Method: A cross-sectional observational study with 240 subjects under the age of five in 12 Integrated Healthcare Center (Posyandu) in Jatinangor. Examinations included parental interviews, Behavioral Observation Audiometry (BOA), Otoacoustic Emissions (OAE), and tympanometry tests. Result: One child (0.4\%) had moderate conductive hearing loss in the left ear, 1 child $(0.4 \%)$ had bilateral severe SNHL, and 7 children $(2.9 \%)$ had profound bilateral SNHL. Conclusion: The incidence of hearing loss in children under five in Jatinangor was $3.8 \%$, with bilateral profound SNHL as the highest number, and the most common cause were prenatal Toxoplasma, Rubella, Cytomegalovirus (CMV) dan Herpes simplex virus (TORCH) infections.
\end{abstract}

Keywords: children under-five, early detection, hearing status

\section{ABSTRAK}

Latar belakang: Pendengaran merupakan salah satu faktor yang sangat berpengaruh dalam proses perkembangan anak. Periode kritis perkembangan pendengaran dan berbicara dimulai dalam 6 bulan pertama kehidupan dan terus berlanjut sampai usia 3 tahun. Badan kesehatan dunia memperkirakan satu sampai tiga dalam seribu kelahiran terdapat kejadian gangguan dengar jenis sensorineural. Deteksi dini gangguan dengar penting untuk dilakukan sehingga diagnosis dapat ditegakkan dan intervensi yang tepat dapat dilakukan sedini mungkin. Tujuan: Untuk mengetahui status pendengaran pada anak usia bawah lima tahun di kecamatan Jatinangor. Metode: Penelitian observasional potong lintang dengan subjek penelitian 240 anak usia bawah lima tahun di 12 Pos Pelayanan Terpadu (Posyandu) Kecamatan Jatinangor. Dilakukan pemeriksaan meliputi wawancara orangtua anak, tes Behavioral Observation Audiometry (BOA), tes Otoacoustic Emissions (OAE) dan tes timpanometri. Hasil: Didapatkan 1 anak $(0,4 \%)$ mengalami gangguan dengar konduktif derajat sedang pada telinga kiri, 1 anak (0,4\%) mengalami gangguan dengar sensorineural derajat berat bilateral, dan 7 anak $(2,9 \%)$ mengalami gangguan dengar sensorineural derajat sangat berat bilateral. Kesimpulan: Angka kejadian gangguan dengar pada balita di kecamatan Jatinangor sebesar 3,8\% dengan gangguan dengar terbanyak berupa sensorineural derajat sangat berat bilateral, dan latar belakang penyebab terbanyak adalah infeksi prenatal Toxoplasma, Rubella, Cytomegalovirus dan Herpes simplex virus (TORCH).

Kata kunci: anak bawah lima tahun, deteksi dini, status pendengaran 
Correspondence address: DR. dr. Wijana, SpTHT-KL(K), FICS, Department of Otorhinolaryngology Head and Neck Surgery, Faculty of Medicine Padjadjaran University / Dr. Hasan Sadikin Hospital, Bandung, Indonesia. Email: wijana@unpad.ac.id.

\section{INTRODUCTION}

Hearing is one of the most important senses in children developmental process particularly in speech development. The critical period of hearing and speech development begins in the first 6 months of life and continues until the age of 3 years. In general, hearing impairment is caused by genetic (hereditary) and nongenetic (acquired) factors. Hearing impairment can be present at birth (prelingual) or occur after the age of 3 years (postlingual) which will affect patient's communication ability. Globally, hearing impairment has become the $4^{\text {th }}$ leading cause of the world main disability. ${ }^{1.2}$

The prevalence of hearing disturbance in newborn and babies is estimated between 1 to 3.47 cases per 1000 live births. ${ }^{2}$ According to World Health Organization (WHO) one to three in a thousand births have sensorineural hearing loss (SNHL). WHO estimates that the prevalence of disabling hearing loss in the world from 42 millions in 1985 had increased to 360 millions in 2010. Seven and half millions of these children were under the age of 5 years. Thirty four millions (7.3\%) from 466 million people with hearing loss are children, with the highest prevalence in South Asia, Asia Pacific, and Sub-Sahara Africa. ${ }^{3}$

Due to that fact, European, American and international groups of experts have recommended the organization of universal newborn hearing screening (UNHS) for years. The main purpose of a UNHS is to lower the age of hearing-impaired children at the time of diagnosis ${ }_{17}$ so that allowing earlier intervention. According to Joint Committee on Infant Hearing ( JCIH), a comprehensive audiological assessment should be performed using Auditory Brainstem Response (ABR), Otoacoustic Emissions (OAE), and tympanometry before 3 months of age, and appropriate intervention should begin before 6 months of age. ${ }^{4}$

Public Health Center (Puskesmas) as the front line in promotion and implementation of public health programs has an important role in surveillance of children growth and development, including the development of hearing function and the presence of hearing loss by implementing an Integrated Healthcare Center (Posyandu). One of Posyandu tasks as its base function is to monitor children's development. Based on data from Sumedang County Health Office, out of 32 Puskesmas in Sumedang county, the highest number of children under-five was found in Jatinangor District Public Health Centers. ${ }^{5}$ Based on this data, the researcher wanted to find out the hearing status of children under five years old in Jatinangor district.

\section{METHOD}

This was a cross-sectional observational study with 240 subjects under the age of five in 12 Integrated Healthcare Center (Posyandu) in 6 villages of Jatinangor district. The study was conducted from July 2018 until September 2018. Research subjects were babies and under-five children registered in Posyandu at Jatinangor District. Posyandu was selected with multistage cluster sampling method, and subjects were chosen by total sampling method. The inclusion criteria were babies and children under five years of age, registered at Posyandu Jatinangor district, and the parents gave consent to let their children joined in this study. The exclusion criteria was babies and under-five with cerumen impaction in one or both ears.

Examinations included parental interviews on the risk of hearing loss according to American Joint Committee on 
Infant Hearing (JCIH) 2007, ENT physical examination, Behavioral Observation Audiometry (BOA), Oto-acoustic Emissions (OAE) and tympanometry tests.

Tympanometry was needed to evaluate the condition of middle ear through a probe tone installed in auditory canal to measure the reflected voice energy by tympanic membrane.

OAE is an electrophysiology test to evaluate the cochlear outer hair cell. It is an non invasive, objective, automatic test, which is easy, quick, and practical, making it very efficient for universal newborn hearing screening (UNHS).

In healthy ears, the OAE could be simply noted down by installing a probe made of sponge to the auditory canal, to give an acoustic stimulus and to receive emission produced by cochlea. Whenever a disturbance of voice happened during voice conduction from external ear, such as debris or cerumen, middle ear disturbances such as otitis media and tympanic stiffness, membrane timpani, then the acoustic stimulus reaching cochlea will be disturbed and the result of emission produced from cochlea will be reduced. OAE instrument was designed to be automatically detecting the presence of emission (pass) or whenever emission was none/decreased the instrument will show (refer). ${ }^{4}$

\section{RESULT}

In this research, from 275 subjects (135 boys and 140 girls) there was 35 children with cerumen impacted, so that only 240 subjects fulfilled inclusion criteria, revealing the highest subject of group age under-five as many as 83 children $(34.6 \%)$.

Hearing loss was found in 9 children (3.8\%) consisted of 1 subject $(0.4 \%)$ suffered unilateral intermediate conductive hearing loss on left ear, 1 subject $(0.4 \%)$ suffered severe sensorineural hearing loss, and 7 subjects $(2.9 \%)$ suffered profound sensorineural hearing loss. This prevalence rate of hearing loss was less than the data report from WHO multicenter study in the year 1998, stating Indonesia, a country in South East Asia as the $4^{\text {th }}$ leading country in the world with hearing loss disability (4.6\%). Distribution of gender and age is shown in Table 2.

Tabel 1. Distribution of gender and age of research subject

\begin{tabular}{|c|c|c|}
\hline Gender and age & $\begin{array}{l}\text { Total } \\
\text { (n) }\end{array}$ & $\begin{array}{c}\text { Percentage } \\
(\%)\end{array}$ \\
\hline \multicolumn{3}{|l|}{ Gender } \\
\hline Male & 120 & 50 \\
\hline Female & 120 & 50 \\
\hline \multicolumn{3}{|l|}{ Age } \\
\hline$<3$ months & 2 & 0,8 \\
\hline $3-<6$ months & 4 & 1,2 \\
\hline $6-<12$ months & 15 & 6,3 \\
\hline $12-<18$ months & 16 & 6,7 \\
\hline $18-<24$ months & 10 & 4,2 \\
\hline $2-<3$ years & 33 & 13,8 \\
\hline $3-<4$ years & 77 & 32,1 \\
\hline $4-<5$ years & 83 & 34,6 \\
\hline Total & 240 & 100 \\
\hline
\end{tabular}


Tabel 2. Distribution of risk factor based on type and hearing loss degree

\begin{tabular}{|c|c|c|c|c|c|c|c|c|}
\hline \multirow[b]{2}{*}{ Risk factor } & \multirow[b]{2}{*}{ Normal } & \multicolumn{3}{|c|}{ Conductive Hearing Loss (CHL) } & \multicolumn{3}{|c|}{$\begin{array}{c}\text { Sensorineural Hearing Loss } \\
\text { (SNHL) }\end{array}$} & \multirow[t]{2}{*}{ Total } \\
\hline & & Moderate & Severe & Profound & Moderate & Severe & Profound & \\
\hline Hereditary & 0 & 0 & 0 & 0 & 0 & 0 & 0 & 0 \\
\hline $\begin{array}{l}\text { Prenatal infection } \\
\text { (TORCH) }\end{array}$ & $1(0,4 \%)$ & 0 & 0 & 0 & 0 & 0 & $5(2,1 \%)$ & $6(2,5 \%)$ \\
\hline $\begin{array}{l}\text { Congenital deafness } \\
\text { syndrome }\end{array}$ & 0 & 0 & 0 & 0 & 0 & 0 & 0 & 0 \\
\hline $\begin{array}{l}\text { Craniofacial } \\
\text { malformation }\end{array}$ & 0 & 0 & 0 & 0 & 0 & 0 & 0 & 0 \\
\hline History of asphyxia & $2(0,8 \%)$ & 0 & 0 & 0 & 0 & 0 & 0 & $2(0,8 \%)$ \\
\hline Very low birth weight & $5(2,1 \%)$ & 0 & 0 & 0 & 0 & $1(0,4 \%)$ & 0 & $6(2,5 \%)$ \\
\hline Hyperbilirubinemia & $1(0,4 \%)$ & 0 & 0 & 0 & 0 & 0 & 0 & $1(0,4 \%)$ \\
\hline $\begin{array}{l}\text { Mechanical ventilator } \\
\text { for at least } 5 \text { days }\end{array}$ & 0 & 0 & 0 & 0 & 0 & 0 & 0 & 0 \\
\hline $\begin{array}{l}\text { History of ototoxic } \\
\text { medicine }\end{array}$ & $2(0,8 \%)$ & 0 & 0 & 0 & 0 & 0 & 0 & $2(0,8 \%)$ \\
\hline Bacterial meningitis & 0 & 0 & 0 & 0 & 0 & 0 & 0 & 0 \\
\hline No risk factor & $220(85 \%)$ & $1(0.4 \%)$ & 0 & 0 & 0 & 0 & $2(0,8 \%)$ & $223(92,9 \%)$ \\
\hline Total & $\begin{array}{c}231 \\
(96,25 \%)\end{array}$ & $1(0,4 \%)$ & 0 & 0 & 0 & $1(0,4 \%)$ & $7(2,9 \%)$ & $240(100 \%)$ \\
\hline
\end{tabular}

Tabel 3. Result of OAE and Tympanometry tests

\begin{tabular}{lccc}
\hline OAE & Normal & $\begin{array}{c}\text { Not } \\
\text { normal }\end{array}$ & Total \\
\cline { 1 - 1 } Tympanometry & & 8 & 239 \\
Normal & 231 & 1 & 1 \\
Abnormal & 0 & 9 & 240 \\
\hline Total & 231 & & \\
\hline
\end{tabular}

\section{DISCUSSION}

Early diagnosis and rehabilitation of congenital hearing loss was needed to achieve an optimal linguistic and cognitive development. Without the right opportunity to learn language, children with hearing loss would be left behind from their age counterparts with normal hearing in areas of cognition, reading, and socio-emotional development. ${ }^{3,6}$
In this research, 2 children $(0.8 \%)$ of 2 months old with bilateral profound sensorineural hearing loss were found without any risk factor. Bielecki I et al. ${ }^{7}$ found $43.47 \%$ normal babies with sensorineural hearing loss without the presence of risk factor. Evidence Non hereditary hearing loss (acquired) in children was majority caused by prenatal TORCH infection. This non genetic hearing disturbance was acquired during mother's pregnancy in the first trimester and at birth. ${ }^{8}$ It was detected in 5 children $(2.1 \%)$ with profound sensorineural hearing loss, and 1 child $(0.4 \%)$ without any hearing loss although he had a history of mother's prenatal TORCH infection. This infection could cause intrauterine growth restriction, microcephaly, seizures, mental retardation, visual organ defect, cerebral palsy, and sensory neural hearing loss (SNHL) as a direct effect of Toxoplasma gondii parasites, 
and of other virus infection such as Rubella, Cytomegalovirus (CMV), Herpes simplex virus (HSV), Varicella zoster virus (VZV) and syphillis which could cause cochlear damage and cell death in Corti organ and stria vascularis. Rubella is the highest risk factor. SNHL is the most common sequelae of congenital rubella infection (58\%) and is mostly seen when maternal rubella infection occurs within the first 16 weeks of pregnancy. ${ }^{8,9}$

Profound bilateral SHNL was found in 1 child $(0.4 \%)$ who had a history of very low birth weight. A delayed process of myelination in very low birth weight baby is also a factor contributing an immaturity and body physiological dysfunction, including hearing function. ${ }^{8,10}$

The prevalence of hearing loss in children under five years of age in Jatinangor district was $3.8 \%$, the highest is bilateral profound sensorineural hearing loss with a history of origin prenatal TORCH infection.

\section{REFERENCE}

1. Dewi YA, Agustian RA. Karakteristik Gangguan Dengar Sensorineural Kongenital pada Anak yang Dideteksi dengan Brainstem Evoked Response Audiometry. MKB. 2011; 43(2): 77-81

2. Neumann K, Chadha S, Tavartkiladze $\mathrm{G}, \mathrm{Bu} \mathrm{X}$, White KR. Newborn and Infant Hearing Screening Facing Globally Growing Numbers of People Suffering from Disabling Hearing Loss. Int. J. Neonatal Screen. 2019;5 (7):1-11.

3. Farinetti A, Raji A, Wu H, Wanna B, Vincent C. International consensus (ICON) on audiological assessment of hearingloss in children. Eur Ann Otorhinolaryngol Head Neck Dis. 2018; 135(1): 41-8.

4. Vos B, Lagasse R, Laveque A. Main outcomes of a newborn hearing screening program in Belgium over six years. Int $\mathbf{J}$ Pediatr Otorhinolaryngol. 2014; 78(2) : 1496-502.
5. Agustin A, Rakhmawati W, Nurlita L. Gambaran Pengetahuan Kader di Posyandu Desa Cipacing Tentang Perkembangan Pada Balita. JKP. 2013; 5(3): 59-64.

6. Paludetti G, Conti G, Di Nardo W, De Corso E, Rolesi R, Picciotti PM, et al. Infant hearing loss: from diagnosis to therapy. Official Report of XXI Conference of Italian Society of Pediatric Otorhinolaryngology. Acta OtoLaryngol Italica. 2012; 32: 347 - 70.

7. Bielecki I, Horbulewicz A, Wolan T. Risk factors associated with hearing loss in infants: An analysis of 5282 referred neonates. Int J Pediatr Otorhinolaryngol. 2011;75: 925 - 30 .

8. Korver AMH, Smith RJH, Van Camp G, Schleiss MR, Bitner-Glindzicz MAK, Lustig LR, et al. Congenital hearing loss. Nat Rev Dis Primers. 2017 (3): 1 - 37.

9. Cohen BE, Durstenfeld A, Roehm PC. Viral Causes of Hearing Loss: A Review for Hearing Health Professionals. Sagepub. Trends in Hearing. 2014;18:1-7.

10. Wroblewska-Seniuk K, Greczka G , Dabrowski P, Harris Szyfter J, Mazela J. Hearing impairment in premature newbornsAnalysis based on the national hearing screening database in Poland. Screening for hearing impairment in premature newborns. PLoS ONE. 2017;12(9):1-15. 